\title{
Social Representations of the Past in Post-conflict Societies: Adherence to Official Historical Narratives and Distrust Through Heightened Threats
}

\author{
Charis Psaltis, Renata Franc, Anouk Smeekes, Maria Ioannou \\ and Iris Žeželj
}

The authors would like to acknowledge the contribution of COST IS 1205 in making the meetings for conceptualizing the paper and the writing up possible.

C. Psaltis $(\square)$

Social and Developmental Psychology, The University of Cyprus,

Nicosia, Cyprus

e-mail: cpsaltis@ucy.ac.cy

R. Franc

Ivo Pilar Institute of Social Sciences, Zagreb 10 000, Croatia

A. Smeekes

ERCOMER, Utrecht University, Utrecht, The Netherlands

M. Ioannou

University College Groningen, University of Groningen, Groningen, The Netherlands

I. Žeželj

Social Psychology, The University of Belgrade, Belgrade, Serbia

(C) The Author(s) 2017

C. Psaltis et al. (eds.), History Education and Conflict Transformation, DOI 10.1007/978-3-319-54681-0_4 


\section{INTRODUCTION}

It is by now well recognized that one of the major obstacles in the cultivation of historical thinking (Seixas 2004) in the formal educational system of post-conflict societies is the collective memory and narratives of the conflict itself (Carretero 2011; Ferro 1984; Makriyianni and Psaltis 2007; McCully 2012; Carretero and Van Alpen 2014; Psaltis et al. 2017). ${ }^{1}$ This is because many of the actors involved in the educational process, teachers, students, parents and policy makers often share social representations of the past, and the conflict in particular, that closely align with the official master narratives characteristic for their conflict ethos, monoperspectival, selective view of history and naïve epistemology (Bar-Tal and Salomon 2006; Psaltis 2016).

In this chapter, we argue based on empirical evidence from three postconflict settings (Cyprus, Serbia and Croatia) that such representations of the past and their uncritical internalization that leads to adherence to master narratives of conflict construct a threatened self and generate distrust towards the outgroup. A threatened self and intergroup distrust are in our opinion obstacles to conflict transformation (Galtung 2000) and to a peaceful settlement of intergroup conflicts.

\section{Representations Based on Belief vs Representations BASED ON KNOWLEDGE}

The main tension in post-conflict societies around history teaching is well captured by the classic distinction by David Lowenthal (1985a, b) between Heritage vs History or by Wertsch (2007) as collective memory vs history, or Seixas (2004) as collective memory vs disciplinary approach to teaching history. This is not a claim of course that academic history is in any way objective and that collective memory is necessarily false. What we are claiming, however, is that there are two basic orientations that capture two distinct epistemological orientations. History teaching can be oriented towards the one or the other orientation depending on curriculum aims (Perikleous 2010), textbook content and structure and the ideological orientations and training of the educators (Psaltis et al. 2011; Makriyanni et al. 2011). The consequences of taking the one or the other orientation for the representations of the past formed in the classroom will be important, not only for communication in the classroom (Goldberg 2013, this volume; Goldberg et al. 2011), the 
cognitive and moral development of the students (Makriyianni and Psaltis 2007) and their historical consciousness (Rüsen 2004), but also for conflict transformation in the wider societal context. In the field of social psychology, Moscovici (1998) makes an important distinction between social representations based on belief and social representations based on knowledge (Psaltis 2016) which captures the epistemological intention that we are implying here. The distinction is premised on the idea that characteristics of beliefs are homogeneous, affective and impermeable to experience or contradiction that leave little scope for individual variation. They are thus similar to the "dogma" characteristics that Lowenthal attributes to approaching the past as an essentialist heritage. By contrast, social representations founded on knowledge are similar to Lowenthal's approach to the past as history since they are more fluid, pragmatic and amenable to the proof of success or failure and leave certain latitude to language, experience and even to the critical features of individuals.

\section{The Social Psychological Contribution}

The social developmental and social psychological literature stands in a privileged position to render intelligible the reasons behind the resiliency of representations of the past based on beliefs, but at the same time it can critically evaluate the consequences of this approach for intergroup relations in their local context. According to Hammack (2010), the tensions around "history wars" is one between theories that present development and the construction of identity in the youth as a benefit and theories that present the development and the construction of identity in the youth as a burden. Identity can be viewed as a burden to the extent that young people come to uncritically appropriate, reproduce and reify the narrative basis of conflict. The view of identity as a burden that characterizes the narrative identity development of youth is derived from a critical account of the hegemonic nature of identity as a received social taxonomy. Such internalization of a reified and polarized narrative of collective identity would curtail the agency the young people might otherwise possess to make meaning of the social world. In this approach, the nonsense of conflict gains meaning by situating oneself in a community whose collective trauma is anchored in a common narrative (Bekerman and Zembylas 2011) as well as a feeling of perceived collective victimization (Bar-Tal et al. 2009). 
On the contrary, the set of theories that view identity as a benefit stress the liberating potential of identities in the context of a collective struggle for recognition of a weak and marginalized group that is forced to face a dominant, more powerful and suppressive group. This position is largely drawing on writings on national liberation, civil rights movement and collective action. From this position, "national liberation struggles have and continue to embrace the strategic use of reified identities to mobilize and motivate individuals for collective action against an oppressive configuration of intergroup relations" (Hammack 2010). The assumption here is that the internalization of national master narratives of collective victimization can become a valuable symbolic resource (Zittoun et al. 2003) for the construction of a patriotic, proud, self and a society that is homogeneous and socially cohesive. The use of a symbolic resource can both enable and constrain certain actions, and in the case of master narratives, it is worth exploring how their structure and content canalizes the past, present and future of the person.

According to Carretero et al. (2012), master narratives have six common features: (a) exclusion-inclusion as a logical operation contributing to establish the historical subject; (b) identification processes that function as both cognitive and affective anchors; (c) frequent presence of mythical and heroic characters and motives; (d) search for freedom or territory as a main and common narrative theme; (e) inclusion of a moral orientation; and (f) A romantic and essentialist concept of both the nation and the nationals. Van Alpen and Carretero (2015) showed that such master narratives create a very problematic interpretation of the relation between past and present which often takes three forms: (a) collapsing past and present; (b) the past is idealized in a way that the present is a decadent version of the past; and (c) relating the past to a teleological end. All three forms of thinking were found to hinder the historical thinking of 16-year-old high school students in Argentina.

The narratives of conflict also sustain a temporal sense of continuity (Smeekes et al. 2017), and this sense of continuity is closely related to self-identification processes. Groups generally tend to have an understanding of their ethnic and national identities as entities that possess a past, present and future (Sani et al. 2008). During the last few years, social psychological researchers started to examine the importance of a sense of continuity between the past, present and future for collective identities. A series of studies by Sani et al. (2008) revealed that the perception that one's group has temporal endurance over time (i.e. 
perceived collective continuity) is associated with stronger attachment to one's ingroup and it bolsters social connectedness with the ingroup. Importantly, however, recent studies found that ingroup members tend to oppose social developments and outgroups that undermine group continuity (Jetten and Hutchison 2011; Jetten and Wohl 2012).

Moreover, an emerging body of research started to address the underlying psychological mechanisms that drive these relationships by examining the role of feelings of collective self-continuity (for an overview, see Smeekes and Verkuyten 2015). Self-continuity refers to having a sense of connection between one's past, present and future self. Following the social identity perspective (Turner and Reynolds 2001), people should be able to derive a sense of self-continuity from their memberships in social groups. Thus, collective self-continuity refers to the feeling that the part of the self that is derived from group membership has temporal endurance.

There are various groups that can provide people with a sense of selfcontinuity, but this is particularly likely for national groups. The reason is that nations are mainly defined and understood as communities that live together through time (e.g. Anderson 1983; Bhaba 1990), and are often perceived as having a shared culture and identity that is passed on from generation to generation (Bar-Tal and Teichman 2005). This identity, according to Anderson, is imagined, but people perceive it as real. From this point of view, continuity is also imagined but perceived as real. In intergroup conflicts, both groups may develop historical narratives that help them to maintain a sense of collective self-continuity. Previous studies indicate that individuals tend to identify with groups that they see as temporally enduring, because this satisfies their need for self-continuity (e.g. Smeekes and Verkuyten 2013, 2014a, b). This is particularly the case when these groups are seen to possess essentialist continuity, which refers to the perception that core features of the group's culture and identity are stable and continuous even for centuries.

Continuity is not the only way in which group members draw on time to understand their group identity. Lowenthal (1985a, b) proposes that the collective past is used to validate national identity in the present in two ways: by preservation and by restoration. Preservation connects to the concept of collective continuity as discussed within social psychological work (e.g. Sani et al. 2008) and refers to the notion that people find comfort in the belief that their social identities have temporal endurance and are therefore likely to believe that "we" are (and should be) the 
way we have always been. This means that most people want to preserve their collective ways of life, symbols and practices in order to maintain a sense of collective continuity. In times of social change and transition, groups may get the feeling that they are losing their connection to "who we were" in the past, and this is likely to result in attempts to restore a sense of collective continuity. Attempting to restore a national culture and identity that is perceived to be lost or undermined is another way in which the past validates the present. That is, people often refer back to the way things were done in the past, such as customs and traditions, in order to legitimize how things should be done in the present. Lowenthal (1985a, b) suggests that preservation and restoration often exist simultaneously. People are likely to preserve their group identity by affirming its continuity over time, and this is alternated with attempts to restore traditions and ways of life that are seen to be undermined by foreign flavours. One manifestation of this alternation between preservation and restoration is feelings of national nostalgia. National nostalgia is understood as a sentimental longing for the good old days of the country. It is a group-based emotion that can be experienced on the basis of one's social identity. Scholars have proposed that national nostalgia emerges in times of social change and transition, because it has a restorative function (Boym 2001; Lowenthal 1985a, b). The reason is that in longing for those good old days of the national past, group members become more aware of the importance of their original national culture and traditions as a basis for preserving their national identity. In other words, national nostalgia can help group members to restore a sense of collective continuity. At the same time, national nostalgia is often an expression of the mourning and regret over these changes that have taken place (Duyvendak 2011). A fond remembrance of the national past can serve as a painful reminder of the good things that are lost, and this is likely to result in attempts to restore "the way we were". Recent work has shown that national nostalgia is related to feelings of threat to the continuity of group identity (Smeekes and Verkuyten 2015) and results in negative attitudes towards immigrant outgroups (e.g. Smeekes et al. 2015).

The focus on group history observed in public discourses over intergroup conflict in various European countries explicitly frames the collective past as the rooted basis for group identity. However, within these discourses there are different representations of what this collective past looks like. This means that people are both capable of understanding 
their group identity as a temporal entity, and to attribute content to its temporality. This latter aspect is relevant for the study of intergroup relations, because depending on the particular historical narratives that are endorsed, people may position themselves favourably or unfavourably towards the presence of others. These historical narratives are socially shared as they are expressed in public and political discourses (Ashmore et al. 2004; Psaltis 2012, 2016). In these discourses, the collective past is often reconstructed and used flexibly to fit the interests of the present (Lowenthal 1985a, b). That is, strategic representations of group history are often employed in politics to justify present arrangements (Reicher and Hopkins 2001).

The historical perspective to group dynamics has been integrated to social psychological research. There is, for instance, a considerable body of research on how representations of historical wrongdoings of ingroups, such as slavery, colonialism and genocide, impact current intergroup relations via group-based emotions (Branscombe and Doosje 2004; Doosje et al. 1998). Group-based emotions refer to the emotions that people can feel on account of their ingroup's behaviour towards others, such as guilt or shame, even when not personally involved in this intergroup conflict. Most studies within this line of research have examined whether experiencing group-based emotions for historical wrongdoings impacts attitudes towards the harmed outgroup. Several studies show that feelings of group-based guilt for past ingroup atrocities are related to reparation and compensation intentions towards the harmed outgroup in the present (e.g. Brown and Cehajic 2008). A related body of research has examined how group members, despite not being directly harmed, regard themselves as victims of past group conflict (i.e. collective victimhood), and how this impacts intergroup relations (Bar-Tal et al. 2009). Furthermore, studies by Liu and colleagues (e.g. Liu and Hilton 2005; Liu and László 2007; Sibley et al. 2008) examined how representations of national history guide current sociopolitical attitudes, such as support for military action, and legitimation of social inequality (Sibley et al. 2008). Importantly, these social representations also hinder the development and attainment of some central historical thinking skills (Seixas 2004) like historical significance, change and continuity, cause and effect and historical empathy (Páez et al. 2017, pp. 491-510; Psaltis et al. 2017).

We argue that something that is missing from the above line of research is the study of historical narratives of intergroup conflict in relation to a basic ingredient of reconciliation which is trust given that trust 
is not only a prerequisite for reaching a political settlement, an organizing principle of identity positions in the representational field of conflict, but also an essential element of the viability of any peace settlement (Psaltis 2012a).

\section{The Present Study}

Our aim in this study was to further our understanding of the way adherence to master narratives of conflict relates to feelings of intergroup threat and distrust. We put into test the hypothesis that adherence to master narratives is associated with intergroup distrust and feelings of threat. We more specifically propose that the positive relationship between (greater) adherence to ingroup's master narratives and (greater) outgroup distrust is mediated by (increased) feelings of threat.

We test this hypothesis in three post-conflict contexts (Cyprus, Serbia and Croatia), all of which are characterized by violent conflicts between ethnic groups. As is explained next, the adversarial ethnic groups in each of these settings have developed their own accounts of the history of their conflict thus resulting in differing and opposing historical narratives. Despite this major similarity, Cyprus, Serbia and Croatia remain to be three qualitatively distinct contexts. Of interest to us was to assess whether the proposed course of relationships between adherence to the ingroup's master narrative and intergroup distrust via feelings of threat could be validated in all three contexts.

The studied "ingroup” in Cyprus was Greek Cypriots, in Serbia it was Serbs and in Croatia it was Croats. The respective outgroups were Turkish Cypriots in Cyprus, Kosovar Albanians in Serbia and Serbs in Croatia. A brief description of the three contexts follows.

Cyprus: The conflict in Cyprus originates in the 1950s when Cyprus was a British colony. Greek Cypriots (82\% of the population) sought for political union with Greece, which elicited the reaction of the Turkish Cypriot minority (18\%) who embarked on a struggle for the partition of Cyprus between Greece and Turkey. In 1960, Cyprus gained its independence and a power sharing partnership between Greek Cypriots and Turkish Cypriots was established along with the Republic of Cyprus. A coup against the Greek Cypriot president in 1974 engineered by the Greek military junta prompted a military intervention by Turkey that led to the division of the island into two ethnically homogeneous areas. 
According to Papadakis (2008), the central nationalistic historical narrative in the Greek Cypriot community (henceforth GC) as represented in history textbooks is one that begins with the arrival of Greeks (14th century BC) in Cyprus that leads to its Hellenization. The moral centre is Greeks (of Cyprus), and the major enemy is Turks. The plot concerns a struggle for survival of the Cypriot Hellenism against foreign conquerors. The "tragic end" of this struggle is the "Barbaric Turkish Invasion" in 1974 and occupation of $37 \%$ of the island's territory since then.

The corresponding Turkish Cypriot (henceforth TC) narrative is one that begins with the arrival of Turks in Cyprus (in 1571 AD), the moral self is Turks (of Cyprus) and the major enemy are Rums (Greek Cypriots). The plot concerns a struggle for survival by the Turks of Cyprus against Greek Cypriot domination. The military intervention of 1974 marks a happy ending of their struggle for survival. For this reason, it is regarded as the "Happy peace operation" by Turkey in Cyprus which saved Turkish Cypriots from a pending union of Cyprus with Greece.

Serbia: Kosovo is a territory located between Albania, Montenegro, Macedonia and Serbia. The region is burdened by history of long-term ethnic tensions between Albanian and Serb population. Following the violent breakdown of former Yugoslavia during the 1990s, an armed conflict erupted in Kosovo in 1998. Between 1998 and 1999, more than 10,000 people were killed and about 3000 were abducted, whilst approximately 800,000 people fled to neighbouring countries (O'Neill 2002). The conflict ended by NATO intervention, after which a UN protectorate secured by international peacekeeping force was established. Kosovo unilaterally declared its independence in 2008, and its status is still disputed by Serbia. Kosovo and Serbian officials are currently engaged in EU-facilitated dialogue aimed at normalizing their relations.

Kosovar Albanians and Serbs have very different narratives explaining the origin and course of the conflict: Kosovar Albanians consider Kosovo's independence reflecting their large majority status, whilst Serbs view the territory as historically belonging to Serbia. Above a territorial claim, Kosovo is a vital national idea for each group (Bieber 2002).

Croatia: Within the context of collapse of communism in Eastern Europe, significant political and historical changes occurred in the Socialist Federal Republic of Yugoslavia. The political leaderships of Slovenia and Croatia (two out of six Yugoslav republics) elected on 
the first multi-party elections proposed a new confederal agreement (October 1990) to other Yugoslav republics, proposing each republic's right to free self-determination. After the Yugoslav state presidency rejected this proposal, in Croatia a referendum for independence was held in May 1991, whereas 93\% of voters (with $83.6 \%$ turnout) voted for independence from Yugoslavia (Jović 2007). However, the ethnic Serbs in parts of Croatia with ethnic Serb majorities boycotted this referendum wanted Croatia to remain a part of Yugoslavia. Croatian independence from Yugoslavia was declared in June 1991, followed by international recognition in January 1992.

The tensions with Serbs minority who opposed Croatian independence escalated in August 1991, and grew into 1991-1995 war between Croatian forces and the Croatian Serbs rebel forces with the help of the JNA and Serbia (UN-ICTY). Around 54\% of Croatian territory inhabited by $36 \%$ of the Croatian population was directly affected by war, and around $26 \%$ of Croatian territory was occupied for several years (Perković and Puljiz 2001). Direct demographic losses counted 22,192 people; out of them, $36.7 \%$ were members of Croatian military forces, $29.8 \%$ civilians, $5.5 \%$ missing Croatian forces and civilians and $28 \%$ missing and killed members of the army of the so-called Republic of Serbian Krajina and Serbian civilians from the same territory (Živić and Pokos 2004).

Dominant narratives about the war 1991-1995 between the two sides are still very different. According to dominant Croatian historical narrative, the 1991-1995 war in Croatia or Homeland war is legitimate international war by which Croatia established its independence and defended itself from Serbian and Slobodan Milošević's aggression and aspirations for so-called Great Serbia (Banjeglav 2013). Such narrative is promoted also by Declaration about Homeland war adopted by Croatian parliament in 2000 (Narodne novine 2000). On the other side, according to dominant Serbs narrative the 1991-1995 war is primarily internal conflict or civil war with emphasis on Serb's suffering (Mirkovic 2000, p. 364; Subotić 2013). 


\section{Methods}

\section{Participants}

Our sample consisted of a total of 478 university students, studying in the capital cities of the three countries under study: Cyprus, Nicosia $(N=145)$; Serbia, Belgrade $(N=173)$; and Croatia, Zagreb $(N=160) .{ }^{1}$ The mean age of the total sample was $21.2(S D=2.47)$, and this was comparable across countries, Cyprus: $M=21.2$ $(S D=2.82)$, Serbia: $M=21.3(S D=2.32)$ and Croatia: $M=21.25$ $(S D=2.34)$. Of the participants who indicated their gender $(9 \%$ was missing), the vast majority were females $(82 \%)$, and males made up 18\%. The gender distribution was similar across countries, Cyprus: $77 \%$ females, Serbia: $81 \%$ females and Croatia: $87 \%$ females.

\section{Procedure}

Participants were recruited from university classes using opportunity sampling. The participation was voluntary and anonymous. Upon agreeing to take part, participants were asked to fill in the questionnaire either electronically or via paper and pencil as truthfully as they could. The master questionnaire was developed in English, and it was translated into the mother tongue of the participants in each country by two independent native speakers. Local research coordinators compared the two versions against one another and corrected minor discrepancies. As this study was part of a larger cross-cultural survey, we are only reporting the variables relevant to the purposes of this paper.

\section{Measures}

Adherence to ingroup's historical narratives was measured by a three-item scale in Serbia and Croatia, and a two-item scale in Cyprus. The items comprising the scale were designed to convey the ingroup's mainstream narrative of the conflict (as it can be found in textbooks and mainstream media) which is typically placing the blame for the eruption or/and the continuation of the conflict on the outgroup(s). The items differed (in content) by country. Examples of items for each country are the following: Cyprus: (1) "In 1974 Turkey invaded Cyprus with the aim of partitioning the country" and (2) "The declaration of the "Turkish 
Republic of Northern Cyprus' prevents the solution of the Cyprus problem"; Serbia: (1) "the Kosovo conflict erupted primarily because Kosovo Albanians wished for Greater Albania" and (2) "Throughout their history, Serbs have been repeatedly forcefully displaced from Kosovo"; and Croatia: (1) "The war in Croatia was entirely a consequence of Serbian aggressive politics" and (2) "War in Croatia happened because the Serbs refused to accept the creation of Croatia as an independent state". Participants assessed their agreement with each statement on a 7-point Likert scale ranging from $1=$ strongly disagree to $7=$ strongly agree. Cronbach's alpha for this scale was 0.76 in Serbia and 0.80 in Croatia, whereas the correlation coefficient in Cyprus where this construct was measured by two items was $0.33, p<0.001$.

Realistic threat was measured by four items which participants had to assess by declaring their agreement or disagreement on a 7-point scale (e.g. in Cyprus: (1) The more power Turkish Cypriots gain in Cyprus, the more difficult it will become for Greek Cypriots; (2) I am afraid that allowing Turkish Cypriots to decide on political issues would mean that Greek Cypriots will have less to say in how this country is run). Cronbach's alpha for this scale was 0.86 (Cyprus: 0.88, Serbia: 0.86, Croatia: 0.77).

Symbolic threat was measured by a four-item scale. Participants had to declare their agreement or disagreement with each of the four statements on a 7-point scale (e.g. in Serbia: (1) Some of the customs and traditions of Albanians undermine the traditional way of life of Serbs; (2) Albanians are beginning to project their identity in a way that I find threatening). The Cronbach's alpha for this scale was 0.78 (Cyprus: 0.73, Serbia: 0.80, Croatia: 0.80).

Group-esteem threat was measured by four items (e.g. Croatia: (1) Serbs have little respect for Croatians; (2) Serbs think positively about Croatians (reverse-coded)). Cronbach's alpha was 0.86 (Cyprus, 0.92; Serbia: 0.85, Croatia: 0.82).

Outgroup trust was measured via three items to which participants had to respond on a 4-point scale. The three items were the following (e.g. Cyprus): (1) Do you think most Turkish Cypriots would try to take advantage of you if they got a chance, or would they try to be fair? (1, definitely try to take advantage; 4, definitely try to be fair), (2) Would you say that most Turkish Cypriots can be trusted or that you can't be too trusting of them? (1, definitely can't be too trusting; 4, definitely can be trusted) and (3) Would you say that most of the time Turkish Cypriots try to be helpful or that mainly they are interested only in themselves? 
(1, definitely interested only in themselves; 4, definitely try to be helpful). Cronbach's alpha was 0.81 for the whole sample (Cyprus: 0.87; Serbia: 0.87; Croatia: 0.75).

\section{RESULTS}

\section{Descriptive Statistics}

Tables 1, 2 and 3 show the means $(M)$ and standard deviations $(S D)$ for all variables, as well as the correlations between variables, in all three contexts. As can be seen in these tables, the mean levels of adherence to ingroup narratives were above the mid-point level (4.0) in all countries suggesting a tendency to overall agree with the ingroup's narrative of the conflict. The means of realistic, symbolic and group-esteem threats were above mid-point (4.0) for Serbia, close to mid-point for Cyprus and slightly below mid-point for Croatia, thus showing that the nature of the

Table 1 Means, SDs and correlations between variables, Cyprus

\begin{tabular}{|c|c|c|c|c|c|c|}
\hline & 1 & 2 & 3 & 4 & 5 & $\operatorname{Mean}(S D)$ \\
\hline $\begin{array}{l}\text { Adherence to ingroup's } \\
\text { historical narrative }\end{array}$ & 1 & $0.25^{* *}$ & 0.39 ** & $0.16^{*}$ & $-0.21^{*}$ & $4.69(1.19)$ \\
\hline Group-esteem threat & & 1 & $0.64^{* *}$ & 0.71 ** & $-0.73^{* *}$ & $3.84(1.26)$ \\
\hline Realistic threat & & & 1 & 0.77 * * & -0.60 ** & $4.74(1.26)$ \\
\hline Symbolic threat & & & & 1 & $-0.66 * *$ & $3.55(1.18)$ \\
\hline Trust towards outgroup & & & & & 1 & $2.34(0.67)$ \\
\hline
\end{tabular}

${ }_{* \star}^{*}<<.05$

${ }^{* *} p<.01$

Table 2 Means, SDs and correlations between variables, Serbia

\begin{tabular}{|c|c|c|c|c|c|c|}
\hline & 1 & 2 & 3 & 4 & 5 & $\operatorname{Mean}(S D)$ \\
\hline $\begin{array}{l}\text { Adherence to ingroup's historical } \\
\text { narrative }\end{array}$ & 1 & 0.54 ** & $0.67 * *$ & 0.59 * * & $-0.33^{* *}$ & $4.56(1.24)$ \\
\hline Group-esteem threat & & 1 & 0.67 ** & $0.66^{* *}$ & -0.39 ** & $4.59(1.13)$ \\
\hline Realistic threat & & & 1 & 0.68 ** & -0.31 ** & $5.09(1.32)$ \\
\hline Symbolic threat & & & & 1 & -0.48 ** & $4.28(1.32)$ \\
\hline Trust towards outgroup & & & & & 1 & $2.73(0.56)$ \\
\hline
\end{tabular}

${ }^{*} p<.05$

${ }^{* *} p<.01$ 
Table 3 Means, SDs and correlations between variables, Croatia

\begin{tabular}{|c|c|c|c|c|c|c|}
\hline & 1 & 2 & 3 & 4 & 5 & $\operatorname{Mean}(S D)$ \\
\hline $\begin{array}{l}\text { Adherence to ingroup's historical } \\
\text { narrative }\end{array}$ & 1 & $0.54^{* *}$ & 0.67 * * & 0.59 ** & $-0.33^{* *}$ & $5.33(1.08)$ \\
\hline Group-esteem threat & & 1 & 0.67 * * & $0.66^{* *}$ & -0.39 ** & $3.30(1.12)$ \\
\hline Realistic threat & & & 1 & $0.68 * *$ & -0.31 ** & $3.44(1.32)$ \\
\hline Symbolic threat & & & & 1 & $-0.48 * *$ & $2.51(1.32)$ \\
\hline Trust towards outgroup & & & & & 1 & $2.10(1.50)$ \\
\hline
\end{tabular}

${ }^{*} p<.05$

${ }^{* *} p<.01$

conflict, or the nature of intergroup relations rather, varies somewhat in the three countries. Finally, the levels of outgroup trust were moderate in the three countries (just above 2 at a 4 -point scale).

The correlations between variables were in the expected direction across contexts, and they were all significant. Adherence to ingroup narratives was found to be positively correlated with all types of threat and negatively correlated with outgroup trust. Greater adherence to ingroup narratives was associated with feeling greater levels of realistic, symbolic and groupesteem threat and being less trusting of the outgroup. Furthermore, all types of threats were found to be negatively correlated with trust: experiencing more realistic, symbolic and group-esteem threat for the outgroup was associated with lower levels of trust towards the outgroup.

We proceeded to test the hypothesized relationships between adherence to ingroup narratives, threats and trust with a path model, using AMOS. We first tested the model with the whole sample and then on each context separately. In this model, adherence to ingroup narratives was inserted as the predicting variable, outgroup trust as the outcome variable and the three types of threats as mediators. The proposed relationships between these variables were that adherence to ingroup narratives would be negatively associated with outgroup trust and that this relationship would be mediated by the three types of threat.

The results of the proposed model on the whole sample mostly supported our hypothesized relationships between variables. Adherence to ingroup narratives was found to be associated with higher realistic threat, $\beta=0.325, p<0.001$, higher symbolic threat, $\beta=0.167, p<0.01$, and higher group-esteem threat, $\beta=0.228, p<0.001$. Higher symbolic and higher group-esteem threat were related to less outgroup trust $(\beta=-0.085, p<0.01, \beta=-0.159, p<0.001$, respectively $)$, but there 
was no significant association between realistic threats and trust. In order to identify the mediators accounting for the indirect effects, we then applied a bootstrapping procedure using 95\% confidence intervals based on 5,000 bootstrap resamples with the use of PROCESS (Preacher and Hayes 2008). In general, adherence to ingroup narratives had a negative total indirect effect on trust, TIE $=-0.055[-0.086,-0.026]$. Two of the three specific indirect effects of adherence to ingroup narrative on trust were significant. The first involved the mediation of symbolic threat, $\mathrm{IE}=-0.014[-0.034,-0.003]$, and the second involved the mediation of group-esteem threat, IE $=-0.035[-0.061,-0.017]$. The indirect effect of realistic threat was not significant, IE $=-.004[-0.026,0.015]$.

The results for the proposed model for each of the three countries are shown in Fig. 1. As can be seen, adherence to ingroup narratives was indeed found to strongly and significantly correlate with every type of threat in all contexts. The only exception to this was a solely marginal effect between adherence to ingroup narrative and symbolic threat in Cyprus. The relationships between threat and outgroup trust were less conclusive, however. In all three contexts, group-esteem threat was found to significantly correlate with outgroup trust in the expected

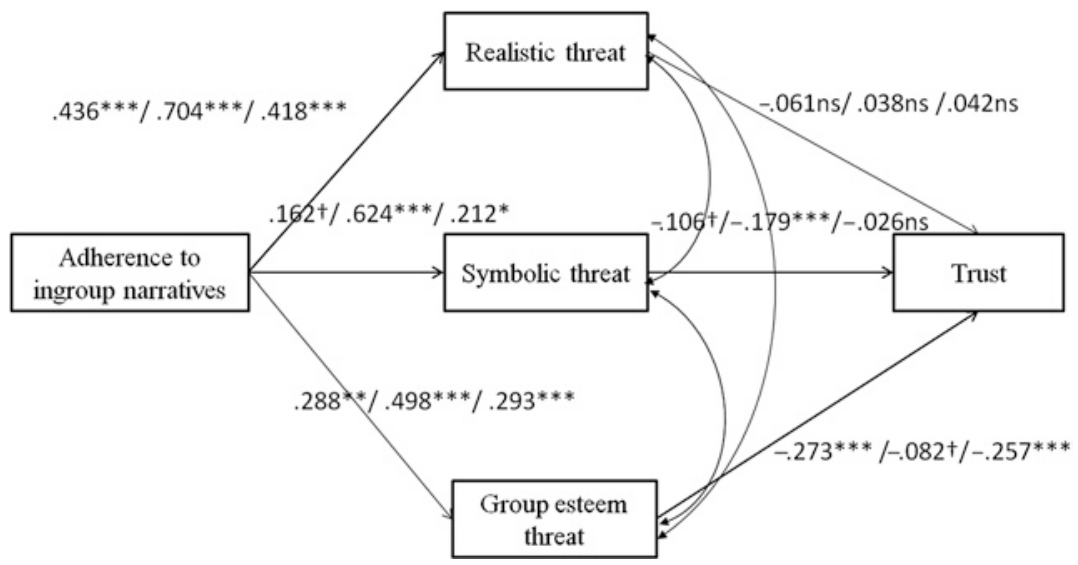

Fig. 1 Effects of adherence to ingroup narratives on outgroup trust, mediated by perceived realistic, symbolic and group-esteem threat. Note Standardized coefficients presented and separated by a slash (Cyprus/Serbia/Croatia); the correlation between the two mediators was accounted for. $\dagger p<0.01,{ }^{*} p<0.05$, ${ }^{* *} p<0.01,{ }^{* * *} p<0.001$ 
direction: higher perceived group-esteem threat associated with lower trust. The effect was only marginal for Cyprus nevertheless. Realistic threat was not found to be significantly related to outgroup trust in any of the three countries. Symbolic threat was found to be associated with outgroup trust only for Serbia, and marginally for Cyprus.

In particular, for Serbia adherence to ingroup narratives had a negative total indirect effect on trust, TIE $=-0.107[-0.179,-0.041]$. One of the three specific indirect effects of adherence to ingroup narrative on trust was significant. This involved the mediation of symbolic threat, IE $=-0.107$ $[-0.180,-0.052]$. The mediation of group-esteem threat, IE $=-0.038$ $[-0.092,0.004]$, and the indirect effect of realistic threat, IE $=0.038$ $[-0.035,0.117]$, were not significant. For Cyprus, adherence to ingroup narratives also had a negative total indirect effect on trust, TIE $=-0.122$ $[-0.216,-0.028]$. One of the three specific indirect effects of adherence to ingroup narrative on trust was significant. This involved the mediation of group-esteem threat, IE $=-0.078[-0.154,-0.020]$. The mediation of symbolic threat, $\mathrm{IE}=-0.017[-0.057,0.001]$, and the indirect effect of realistic threat, $\mathrm{IE}=0.027[-0.091,0.020]$, were not significant. Similarly, for Croatia adherence to ingroup narratives also had a negative total indirect effect on trust, TIE $=-0.063[-0.118,-0.021]$. One of the three specific indirect effects of adherence to ingroup narrative on trust was significant. This involved the mediation of group-esteem threat, $\mathrm{IE}=-0.075[-0.128,-0.035]$. The mediation of symbolic threat, $\mathrm{IE}=-0.005[-0.035,0.013]$, and the indirect effect of realistic threat, $\mathrm{IE}=0.017[-0.011,0.053]$, were not significant.

\section{Discussion}

Our research showed that internalizing the ingroup's account of historical events related to the conflict leads to viewing the outgroup as a threat to the ingroup and, as such, a group that should not be trusted. More specifically, the results replicate our hypothesis that adherence to ingroup narratives would be related to more distrust towards the outgroup via heightened feelings of threat coming from the outgroup(s).

The course of relationships as was tested via the path models (i.e. adherence to ingroup narrative leading to greater perceived threats, leading to outgroup distrust) is in line with the ontogenetic perspective of social representations according to which children find out about their past victimization (Bar-Tal and Teichman 2005) by an outgroup at a 
very early age (see Psaltis 2015; Psaltis et al. 2015) and then internalize master narratives of collective victimization. This internalization gradually leads to a more coherent and abstract notion of realistic, symbolic and group-esteem threats which are mostly future oriented (Stephan et al. 2009).

We are, of course, aware that claims for causality cannot really be made given the cross-sectional type of our data, and we therefore encourage longitudinal and/or developmental research which would back up with evidence the proposed sequential order, i.e. one extending from adherence to narratives to perceived threat and distrust. Furthermore, we do not claim that this sequential order represents the only course of relationships between adherence to ingroup historical narratives and intergroup relations. Smeekes et al. (2017) have, for instance, demonstrated in one study that when people feel threatened in times of social change or transition, they could find a symbolic "shelter" through further adherence to narratives of continuity. This direction of causality is opposite to the one that was tested in the study presented in this chapter even though the nature of the associations remains constant (a positive relationship between perceived threat and adherence to ingroup's narrative).

A second finding of this study is that the mediated relationship between adherence to ingroup narratives and distrust was replicated in all three contexts. The only difference across contexts regarded the type of threat that significantly mediated the relationship. Symbolic threat emerged as a significant mediator in Serbia, and group-esteem threat in Cyprus and Croatia. A more in-depth analysis of probably the content of the narrative and the representation of the enemy would possibly explain the aforementioned differences. Such analysis forms a possible avenue of future research on the topic. Interestingly, realistic threat did not mediate the relationship between adherence to ingroup narratives and outgroup distrust in any of the contexts. We contend that this is because the interethnic conflicts in the three contexts are not characterized by violence at this point in time.

An extrapolation of the present findings is that the uncritical internalization of the historical narrative of the ingroup is counterproductive to the aim of conflict transformation in conflict societies. If the communities involved in post-conflict societies decided to resolve their differences through dialogue and negotiation, then the role of master narratives becomes destructive as it reinforces division, sectarianism and 
competition by escalating conflict and distrust. Contrary to what is often argued by the heritage, nationalist or romantic approach to nation building, the sense of self created is not one of security but one of a threatened and fragile self which is what Bar-Tal and Teichman (2005) called a "siege mentality". Identity construction on the basis of conflict narratives is thus not liberating as it might be argued by theoretical approaches or politicians who support the heritage approach. On the contrary, it is about constructing a fragile and threatened self which is distrustful of those with whom they need to co-operate to end violence, division or conflict.

Thinking about the ramifications of the present findings for history teaching, what could in fact be liberating is reflection on the structure and function of historical conflict narratives as social representations by both teachers and students. In this way, children, youth and adults can understand the consequences of the internalization of master narratives for conflict transformation.

To conclude, the heritage or the romantic identity building approach in history teaching can thus be criticised on all four grounds: pedagogical, epistemological, moral and political. Pedagogically, it is based on an outdated model of a transmission metaphor given that it is mostly delivered by educators as a communication type that Moscovici described as propaganda (Kello and Wagner (Chap. 8)). Epistemologically, it is based on naive realism since it promotes the single truth of the nation, which is an outdated epistemological stance. Morally, the idea of manipulating, silencing or hiding parts of the past from students is unacceptable. Politically, it reinforces conflict instead of resolving it.

As Barton and Levstick (2004) argue, students have to examine the impact of telling any particular narrative, or any set of narratives, as well as the consequences of students' narrative simplifications. For the disciplinary approach, there is an important take-home message from the present findings: history teachers need to familiarize themselves with relevant social psychological research and have in their "toolbox" the main findings of research such as the present one. Given the well-established findings that master narratives pose a threat to the cultivation of the historical thinking of students (Carretero 2011; Lopez et al. 2012), the present should be read as adding support to the idea of moving from the disciplinary to an interdisciplinary approach (see Psaltis et al. 2017) to the study of historical culture and consciousness in the history classroom. The cultivation of a critical historical and reflective consciousness that recognizes the socially 
constructed nature of master narratives and their pernicious effects for conflict transformation is an essential element of such an approach that could be termed transformative history teaching. Finally, both first and second-order concepts of history teaching could be enriched by a better understanding of concepts that come directly from the social psychological field such as "threats", "social identity", "prejudice", "distrust", "conflict transformation" and "reconciliation" and above all "master narratives".

\section{Notes}

1. There were missing cases on some variables. Participants who had a missing value on any one variable tested were excluded from the sample. This led to a sample of $N=427$ (Cyprus: $N=112$; Serbia: $N=161$; Croatia: $N=154)$. Results reported in this chapter are based on this sample.

\section{REFERENCES}

Anderson, B. (1983). Imagined communities: Reflections on the origin and spread of nationalism. London: Verso.

Ashmore, R. D., Deaux, K., \& McLaughlin-Volpe, T. (2004). An organizing framework for collective identity: Articulation and significance of multidimensionality. Psychological Bulletin, 130, 80-114.

Banjeglav, T. (2013). conflicting memories, competing narratives and contested histories in croatia's post-war commemorative practices. Politička Misao, 49(5), 7-31.

Bar-Tal, D., \& Čehajić-Clancy, S. (2013). From collective victimhood to social reconciliation: Outlining a conceptual framework. In D. Spini, D. Čorkalo Biruški, \& G. Elcheroth (Eds.), War and Community: Collective experiences in the former Yugoslavia. New York: Springer.

Bar-Tal, D., \& Salomon, G. (2006). Israeli-Jewish narratives of the IsraeliPalestinian conflict: Evolvement, contents, functions and consequences. In R. I. Rotberg (Ed.), Israeli and Palestinian narratives of conflict: History's double Helix. Bloonington: Indiana University Press.

Bar-Tal, D., \& Teichman, Y. (2005). Stereotypes and prejudice in conflict: Representations of Arabs in Israeli Jewish society. Cambridge: Cambridge University Press.

Bar-Tal, D., Chernyak-Hai, L., Schori, N., \& Gundar, A. (2009). A sense of selfperceived collective victimhood in intractable conflicts. International Review of the Red Cross, 91(874), 229-258.

Barton, K. C., \& Levstik, L. S. (2004). Teaching history for the common good. Mahwah: Lawrence Erlbaum Associates. 
Bekerman, Z., \& Zembylas, M. (2011). The emotional complexities of teaching conflictual historical narratives: The case of integrated Palestinian-Jewish schools in Israel. Teachers College Record, 113(5), 1004-1030.

Bhabha, H. (1990). Nation and narration. London, UK: Routledge.

Bieber, F. (2002). Nationalist mobilization and stories of Serb suffering: The Kosovo myth from 600th anniversary to the present. Rethinking History, 6, 95-110.

Billig, M. (1995). Banal Nationalism. London: Sage.

Boym, S. (2001). The future of nostalgia. New York: Basic Books.

Branscombe, N. R., \& Doosje, B. (2004). Collective guilt: International perspectives. Cambridge: Cambridge University Press.

Brown, R., \& Čehajić, S. (2008). Dealing with the past and facing the future: Mediators of collective guilt and shame in Bosnia and Herzegovina. European Journal of Social Psychology, 38, 669-684.

Carretero, M. (2011). Constructing patriotism. Teaching history and memories in global worlds. Charlotte: Information Age Publishing.

Carretero, M., \& Van Alphen, F. (2014). Do master narratives change among high school students? Analyzing national historical representations characteristics. Cognition and Instruction, 32(3), 290-312.

Carretero, M., Asensio, M., \& Rodriguez-Moneo, M. (Eds.). (2012). History education and the construction of national identities. Charlotte: Information Age Publishing.

Carretero, M., Lopez, C., Gonzalez, M. F., \& Rodriguez-Moneo, M. (2012). Students historical narratives and concepts about the nation. In M. Carretero, M. Asensio, \& M. Rodriguez Moneo (Eds.), History education and the construction of national identities (pp. 153-170). Charlotte: Information Age Publishing.

Doosje, B., Branscombe, N. R., Spears, R., \& Manstead, S. R. (1998). Guilty by association: When one's group has a negative history. Journal of Personality and Social Psychology, 75, 872-886.

Duyvendak, J. (2011). The politics of home: Belonging and nostalgia in Western Europe and the United States. Basingstoke, UK: Palgrave.

Ferro, M. (1984). The use and abuse of history, or, how the past is taught to children. London: Routledge.

Galtung, J. (2000). Conflict transformation by peaceful means: The Transcend method. United Nations.

Goldberg, T. (2013). "It's in my veins": Identity and disciplinary practice in students' discussions of a historical issue. Theory \& Research in Social Education, $41(1), 33-64$.

Goldberg, T., Baruch, B. B., \& Porat, D. (2011). "Could they do it differently?": Narrative and argumentative changes in students' writing following discussion of "hot" historical issues. Cognition and Instruction, 29(2), 185-217. 
Hammack, P. (2010). Identity as burden or benefit? youth, historical narrative, and the legacy of political conflict. Human Development, 53, 173-201.

Jetten, J., \& Hutchison, P. (2011). When groups have a lot to lose: Historical continuity enhances resistance to a merger. European Journal of Social Psychology, 41, 335-343.

Jetten, J., \& Wohl, M. J. A. (2012). The past as a determinant of the present: Historical continuity, collective angst, and opposition to immigration. European Journal of Social Psychology, 42, 442-450.

Jović, D. (2007). The slovenian-croatian confederal proposal: A tactical move or an ultimate solution? In L. J. Cohen \& J. Dragović-Soso (Eds.), State collapse in South-Eastern Europe: New perspectives on Yugoslavia's disintegration (pp. 249-280). USA: Purdue University Press.

Liu, J. H., \& Hilton, D. J. (2005). How the past weighs on the present: Social representations of history and their role in identity politics. British Journal of Social Psychology, 44, 537-556.

Liu, J. H., \& László, J. (2007). A narrative theory of history and identity: Social identity, social representations, society and the individual. In G. Moloney \& I. Walker (Eds.), Social representations and identity: Content, process and power (pp. 85-107). London, UK: Palgrave MacMillan.

Lopez, C., \& Carretero, M. (2012). Identity construction and the goals of history education. In M. Carretero, M. Asensio, \& M. Rodriguez-Moneo (Eds.), History education and the construction of national identities (pp. 139-150). Charlotte: Information Age.

Lowenthal, D. (1985a). The past is a foreign country. Cambridge: CUP.

Lowenthal, D. (1985b). The heritage crusade and the spoils of history. Cambridge: CUP.

Makriyianni, C., \& Psaltis, C. (2007). History teaching and reconciliation. Cyprus Review, 19, 43-69.

Makriyianni, C., Psaltis, C., \& Latif, D. (2011). History teaching in Cyprus. In E. Erdmann \& W. Hasberg (Eds.), Facing mapping, bridging diversity: Foundations of a European discourse on history education, part 1 (pp. 91-138). Germany: Wochen Schau Wissenschaft.

McCully, A. (2012). History teaching, conflict and the legacy of the past. Education, Citizenship and Social Justice, 7(2), 145-159.

Mirkovic, D. (2000). The historical link between the Ustasha genocide and the Croato-Serb civil war: 1991-1995. Journal of Genocide Research, 2(3), 363-373.

Moscovici, S. (1998). The History and actuality of social representations. In U. Flick. (Ed.), The Psychology of the social, (pp. 209-247). Cambridge: Cambridge University Press.

Narodne novine, [Official Gazete ], 2000: Deklaracija o Domovinskom ratu [Declaration on the Homeland War], www.nn.hr, no. 102.

O’Neill, W. G. (2002). Kosovo: An unfinished peace. Boulder, Co.: Lynne Rienner. 
Páez, D., Bobowic, M., \& Liu, J. H. (2017). Social representations of the past and competences in history education. In M. Carretero, S. Berger, \& M. Grever (Eds.), Handbook of research in historical culture and history education, (pp. 491-510). UK: Palgrave Macmillan.

Papadakis, Y. (2008). Narrative, memory and history in divided Cyprus: A comparison of school books on the history of Cyprus. History \& Museum, 20, 128-148.

Perikleous, L. (2010). At a crossroad between memory and thinking: The case of primary history education in the Greek Cypriot educational system, Education 3-13. International Journal of Primary Elementary and Early Years Education, 38(3), 315-328.

Perković, M., \& Puljiz, V. (2001). Ratne štete, izdaci za branitelje, žrtve i stradalnike rata u Republici Hrvatskoj [War damages and the expenditure for the veterans and victims of the war in the Republic of Croatia]. Revija za socijalnu politiku, 8(2), 235-238.

Psaltis, C. (2012). Intergroup trust and contact in transition: A social representations perspective on the Cyprus conflict. In I. Markova \& A. Gillespie (Eds.), Trust and conflict: Representations, culture and dialogue (pp. 83-104). London: Routledge.

Psaltis, C. (2015). Genetic social psychology From microgenesis to ontogenesis and sociogenesis... and back. In C. Psaltis, A. Gillespie, \& A. N. P. PerretClermont (Eds.), Social relations in human and societal development. UK: Palgrave, Macmillan.

Psaltis, C. (2016). Collective memory, social representations of intercommunal relations and conflict transformation in divided Cyprus. Peace and Conflict: Journal of Peace Psychology, 22(1), 19-27.

Psaltis, C., Gillespie, A., \& Perret-Clermont, A. N. P. (Eds.). (2015). Human relations in human and societal development. UK: Palgrave/Macmillan.

Psaltis, C., Lytras, E., \& Costache, S. (2011). History educators in the Greek Cypriot and Turkish Cypriot community of Cyprus: Perceptions, beliefs and practices. Nicosia: UNDP-ACT.

Psaltis, C., McCully, A., Agbaria, A., Makriyianni, C., Pingel, F., Karahasan, H., Carretero, M., Oguz, M., Choplarou, R., Philippou, S., Wagner, W., \& Papadakis, Y. (2017). Recommendations for the History Teaching of Intergroup Conflicts. COST IS 1205 Working Group. Retrieved 9 July 2017 from http:// docs.wixstatic.com/ugd/89ca3b_a592bbe79ece4d218cbf9858928b5d10.pdf.

Reicher, S., \& Hopkins, N. (2001). Self and nation. London: Sage Publications.

Rüsen, J. (2004). Historical consciousness: Narrative structure, moral function, and ontogenetic development. In P. Seixas (Ed.), Theorizing historical consciousness (pp. 63-85). Toronto, Canada: University of Toronto Press. 
Sani, F., Bowe, M., \& Herrera, M. (2008). Perceived collective continuity: Seeing groups as temporally enduring entities. In F. Sani (Ed.), Self continuity: Individual and collective perspectives (pp. 159-172). Hove: Psychology Press.

Seixas, P. (Ed.). (2004). Theorizing historical consciousness. Toronto: University of Toronto Press.

Sibley, C. G., Liu, J. H., Duckitt, J., \& Khan, S. S. (2008). Social representations of history and the legitimation of social inequality: The form and function of historical negation. European Journal of Social Psychology, 38, $542-565$.

Smeekes, A., \& Verkuyten, M. (2013). Collective self-continuity, group identification and in-group defense. Journal of Experimental Social Psychology, 49, 984-994.

Smeekes, A., \& Verkuyten, M. (2014a). Perceived group continuity, collective self-continuity and ingroup identification. Self and Identity, 13, 663-680.

Smeekes, A., \& Verkuyten, M. (2014b). When national culture is disrupted: Cultural continuity and resistance to Muslim immigrants. Group Processes and Intergroup Relations, 17, 45-66.

Smeekes, A., \& Verkuyten, M. (2015). The presence of the past: Identity continuity and group dynamics. European Review of Social Psychology, 26(1), 162202.

Smeekes, A., McKeown, S., \& Psaltis, C. (2017). Endorsing narratives under threat: Maintaining perceived collective continuity through the protective power of ingroup narratives in Northern Ireland and Cyprus. Journal of Social and Political Psychology

Stephan, W. G., Ybarra, O., \& Rios Morrison, K. (2009). Intergroup threat theory. In T. Nelson (Ed.), Handbook of Prejudice (pp. 43-59). Mahwah, NJ: Lawrence Erlbaum Associates.

Subotic, J. (2013). Remembrance, Public Narratives, and Obstacles to Justice in the Western Balkans. Studies in Social Justice, 7(2), 265-283.

The United Nations International Criminal Tribunal for the Former Yugoslavia ("UN-ICTY") Croatia-1991-1995. Retrieved 15 July, 2017 http://www. icty.org/en/about/what-former-yugoslavia/conflicts.

Turner, J. C., \& Reynolds, K. J. (2001). The social identity perspective in intergroup relations: Theories, themes, and controversies. In R. Brown \& S. Gaertner (Eds.), Blackwell handbook of social psychology (Vol. 4, pp. 133152). Intergroup processes Oxford, UK: Blackwell.

Van Alphen, F., \& Carretero, M. (2015). The construction of the relation between national past and present in the appropriation of historical master narratives. Integrative Psychological and Behavioral Science, 49(3), 512-530. 
Wertsch, J. V. (2007). Collective Memory. In J. Valsiner \& A. Rosa (Eds.), The Cambridge handbook of pociocultural psychology (pp.625-644). Cambridge: Cambridge University Press.

Zittoun, T., Duveen, G., Gillespie, A., Ivinson, G., \& Psaltis, C. (2003). The use of symbolic resources in developmental transitions. Culture \& Psychology, 9, $415-448$.

Živić, D., \& Pokos, N. (2004). Demografski gubitci tijekom domovinskog rata kao odrednica depopulacije Hrvatske (1991-2001) [Demographic losses during the homeland war as a determinant of depopulation in Croatia (1991$2001)$ ]. Društvena istraživanja, 13(4-5), 727-750.

\section{Authors' Biography}

Charis Psaltis is an Associate Professor of Social and Developmental Psychology at the University of Cyprus. His research interests fall in the areas of genetic social psychology, social interaction in learning and cognitive development, social representations of gender, intergroup contact and intergroup relations in Cyprus and other post-conflict societies, development of national identities and history teaching and collective memory. He published papers in Journal of Personality and Social Psychology, European Journal of Social Psychology, British Journal of Developmental Psychology, Culture os Psychology and Human Development. Since 2014, he is a member of the Editorial Board of the British Journal of Developmental Psychology and since 2015 Associate Editor of European Journal of Psychology of Education. In April 2014, his book co-authored with Anna Zapiti Interaction, Communication and Development: Psychological Development as a social process was published by Routledge, and in 2015 , his co-edited volume Social Relations in Human and Societal Development by Palgrave Macmillan.

Renata Franc is a Scientific Adviser at the Ivo Pilar Institute of Social Sciences and Full Professor of Social and Political Psychology at the University of Zagreb. Her research interests include social attitudes, values, intergroup relations and conflict, political participation and quality of life. Currently, she is a member of the research team on projects PROMISE (PROMoting Youth Involvement and Social Engagement: Opportunities and challenges for "conflicted" young people across Europe, EU H2020, 2016-2019) and CRO WELL (Croatian Longitudinal Study on Well-Being, Croatian Science Foundation 2015-2019). Since 2009, she is Editor-in-Chief of the Croatian international social sciences journal Društvena istraživanja (Social research-Journal for general social issues). Most recently, she is a co-author of The situation of children's and women's rights in Croatia-update (UNICEF Office for Croatia 2015) and "Personal Security and Fear of Crime as Predictors of Subjective Well-Being," in D. Webb, E. WillsHerrera (Eds.) Subjective Well-Being and Security (Springer, 2012). 
Anouk Smeekes is an Assistant Professor of Interdisciplinary Social Sciences at the European Research Centre on Migration and Ethnic Relations (ERCOMER) at Utrecht University (the Netherlands). Her research in the field of Social Psychology focuses on historical representations, national identity, identity motivation, group-based emotions (national nostalgia) and intergroup relations. She published various papers on these topics in British Journal of Social Psychology, Journal of Experimental Social Psychology, Personality and Social Psychology Bulletin, European Review of Social Psychology and International Journal of Intercultural Research. Her Ph.D. dissertation published in 2014 titled "The presence of the past: Historical rooting of national identity and current group dynamics" won the Rae and Dr. Dan Landis Outstanding Dissertation Award of the International Academy for Intercultural Research (IAIR) in 2015.

Maria Ioannou is a Tutor at the University College Groningen, University of Groningen. Her research interests fall in the area of intergroup relations, intergroup contact and prejudice reduction. Her $\mathrm{PhD}$ thesis focused on comparing the effectiveness of direct and indirect types of intergroup contact between Greek and Turkish Cypriots in Cyprus. Part of this work was published in the journal Group Processes o International Relations. She is also interested in how scientific research can inform policies. The work she undertook while working in the civil society sector led to the co-authoring of a book publication entitled Predicting Peace: The Social Cobesion and Reconciliation Index as a Tool for Conflict Transformation.

Iris Žeželj is an Assistant Professor of Social Psychology at the University of Belgrade. Her research focuses on two areas: social cognition and intergroup relations. More specifically, she investigates memory biases, motivated cognition, attitude-behaviour relations, and ethnic, national and social identities in the post-conflict regions and the role of direct and online contact in prejudice reduction. Her research draws from a variety of methods, from laboratory, field experiments and social games, to interviews and focus groups, to large cross-cultural surveys, and tries to address real-life issues of ethnic, religious and gender discrimination. She published in Social Psychology, British Journal of Social Psychology, Journal of Applied Social Psychology and Computers in Human Behavior. She is currently co-editing a volume entitled Social Identities in Western Balkans by Palgrave Macmillan. 
Open Access This chapter is licensed under the terms of the Creative Commons Attribution 4.0 International License (http://creativecommons.org/licenses/ by $/ 4.0 /)$, which permits use, sharing, adaptation, distribution and reproduction in any medium or format, as long as you give appropriate credit to the original author(s) and the source, provide a link to the Creative Commons license and indicate if changes were made.

The images or other third party material in this chapter are included in the chapter's Creative Commons license, unless indicated otherwise in a credit line to the material. If material is not included in the chapter's Creative Commons license and your intended use is not permitted by statutory regulation or exceeds the permitted use, you will need to obtain permission directly from the copyright holder.

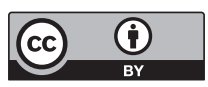

